\title{
Nutritional Factors in Relation to Growth and Fat Synthesis in Mortierella vinacea
}

\author{
By C. G. C. CHESTERS AND J. F. PEBERDY \\ Department of Botany, University of Nottingham,
}

(Received 20 April 1965)

\begin{abstract}
SUMMARY
Growth and fat synthesis in Mortierella vinacea are influenced by a number of nutritional factors. Monosaccharide carbohydrates provided the best carbon source for growth and fat synthesis. Organic nitrogen substrates were inferior to ammonium phosphate for fat accumulation, although high yields of mycelium were obtained. These media probably enhanced protein synthesis. The balance between carbon and nitrogen in the culture medium influenced the rate at which fat synthesis occurred. High concentrations of carbohydrate (glucose) resulted in large yields of mycelium with a high fat content.
\end{abstract}

\section{INTRODUCTION}

Many fungi are now known which have the ability to synthesize intracellular fat from carbohydrates supplied in the culture medium (Woodbine, 1959). Several detailed investigations have been carried out with species of the genera Penicillium, Aspergillus and Fusarium and these have shown that the synthesis of fats by fungi is controlled by a number of nutritional factors.

Although species of Mortierella are common isolates from soils there have been relatively few studies on the physiology of this group of fungi. The proteolytic activity of a number of species has been demonstrated (Wetter, 1952; Turner, 1956) and fat synthesis in Mortierella alpina has been investigated by Galloway (1949) and Woodbine, Gregory \& Walker (1951). A closer study of fat synthesis by species of Mortierella seemed worthy of attention, and it was thought interesting, therefore, to extend the study on growth and fat synthesis with one of these fungi. $\boldsymbol{M}$. vinacea was selected after preliminary investigations using seven species.

\section{METHODS}

The organism. The strain of Mortierella vinacea Dixon-Stewart used was kindly supplied by Mrs M. Turner of the Botany Department, University of Nottingham (Un. Nott. no-133 obtained from C.B.S.). Cultures were maintained on slopes of potato glucose agar and were subcultured every 4 weeks. Cultures for the preparation of inocula were grown on malt extract agar in $8 \mathrm{oz}$. medical flat bottles.

Composition of media, inoculation and incubation. The basal mineral salts medium used in all experiments contained the following (g./100 ml.): $\mathbf{K H}_{2} \mathbf{P O}_{4}, 0.04$; $\mathrm{MgSO}_{4} .7 \mathrm{H}_{2} \mathrm{O}, 0.005 ; \mathrm{FeCl}_{3}, 0.001$. To this solution carbon and nitrogen sources were added as required, and in other experiments glucose and $\left(\mathrm{NH}_{4}\right)_{2} \mathrm{HPO}_{4}$ in a 
range of concentrations. The medium was adjusted to $\mathrm{pH} 6 \cdot 5$ before autoclaving. The solutions of $\mathrm{KH}_{2} \mathrm{PO}_{4}$ and $\mathrm{FeCl}_{3}$ were autoclaved separately and afterwards were mixed with the bulk of the medium contained in cotton-wool-plugged $250 \mathrm{ml}$. conical flasks. The final volume of the mixed solutions was $100 \mathrm{ml}$. All solutions were autoclaved at $108^{\circ}$ for $30 \mathrm{~min}$.

On cooling, the flasks were inoculated with a spore suspension containing about $1 \times 10^{6} \mathrm{spores} / \mathrm{ml}$. Spore suspensions were prepared in sterile distilled water from a 7-day culture of the fungus growing on malt extract agar. Hyphal fragments were removed from the suspension by filtration through sterile glass wool. The spore content of a suspension was determined with a counting chamber; and colony counts were made on potato glucose agar. One ml. of spore suspension was added to each of the culture flasks which were then placed on a shaker in a constant temperature room at $20^{\circ}$.

In some experiments the cultures were harvested after 9 days; in others the cultures were harvested at intervals over an incubation period of 15 or more days. A set of three or five flasks was withdrawn at each sampling time. The mycelium developed as numerous small discrete pellets which were filtered off on weighed papers, dried, re-weighed and, together with samples of culture filtrates, were set aside for analysis.

Estimation of fat. The extraction of fat from dried mycelium was done in a multiple Soxhlet apparatus. Light petroleum (b.p. 40-60 $)$ was used as solvent and the extraction was done for $24 \mathrm{hr}$. The solvent was then distilled off, and the residual fat weighed after drying at $60^{\circ}$.

Analyses of culture filtrates. Glucose concentration in culture fluids was estimated by the anthrone method (Yemm \& Willis, 1954). Spectrophotometric readings were made on a Hilger Spectrophotometer with Ilford orange filter no. 607 and $5 \mathrm{~mm}$. cells.

Nitrogen estimations were made by a modified micro-Kjeldahl method (E. C. Cocking, personal communication). A sample (usually $1 \mathrm{ml}$.) of diluted culture filtrate was boiled for several hours with $0.2 \mathrm{ml}$. of $1 \%(\mathrm{w} / \mathrm{v})$ solution of selenium dioxide in $50 \%(\mathrm{v} / \mathrm{v})$ sulphuric acid. The contents of the tube (about $0 \cdot 1 \mathrm{ml}$.) were diluted to $3 \mathrm{ml}$. with distilled water; $1 \mathrm{ml}$. of this solution was mixed with $8 \mathrm{ml}$. distilled water and $1 \mathrm{ml}$. Nessler's solution. The extinction of the solutions was measured on the spectrophotometer, with Ilford spectrum violet filter no. 601 and $1 \mathrm{~cm}$. cells.

\section{RESULTS}

Fat synthesis from different carbon sources

Several different carbon sources were incorporated with $\left(\mathrm{NH}_{4}\right)_{2} \mathrm{HPO}_{4}$ in the basal mineral salts solution. The cultures were harvested after 9 days.

Of the five carbon sources used, maltose gave the best yield of mycelium and a high degree of fat accumulation. Mycelium production on glucose was not so good, although this carbohydrate was as good as maltose for fat synthesis. Whilst supporting good mycelium formation, lactose was not a carbon source readily converted to fat. In contrast both starch and sodium acetate supported poor growth, but the mycelium contained a large proportion of fat. It would appear, therefore, that carbon sources supporting the production of large amounts of mycelium do not necessarily stimulate fat synthesis. These results are summarized in Table 1. 


\section{Fat symthesis with different nitrogenous substrates}

The yields of mycelium and fat obtained after 9 days are shown in Table 2.

Like other members of the group, Mortierella vinacea utilized various organic nitrogen sources; growth on these substrates was better than with ammonium

Table 1. Formation of fat by Mortierella vinacea groton on various carbon sources

Concentration of carbon gource $1 \mathrm{~g} / 100 \mathrm{ml}$. and $\left(\mathrm{NH}_{4} \mathrm{HPO}_{4} 0.05 \mathrm{~g} / 100 \mathrm{ml}\right.$. Cultures havvested after 9 days. Values given are the means from five flasks with atandard devistions.

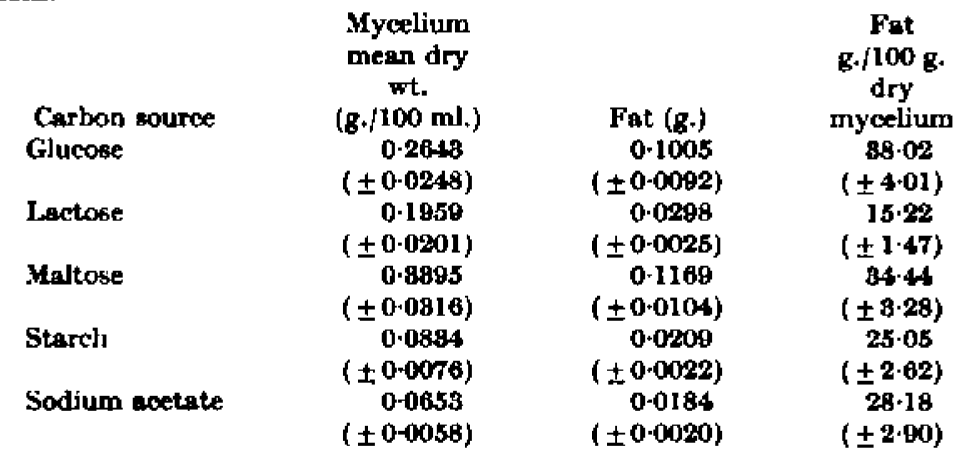

Table 2. Formation of fat by Mortierella vinacea grown on various sources of nitrogen

Medium was made up of basal mineral salts medium $+1 \%(w / v)$ glucose + nitrogen source added to give a thal concentration of $1 \mathrm{mg}$. $/ 100 \mathrm{ml}$. medium. Cultures harveated ater 9 days, Values are means from five flasks with standard deviations.

\begin{tabular}{|c|c|c|c|c|c|}
\hline $\begin{array}{l}\text { Nitrogen } \\
\text { source }\end{array}$ & $\begin{array}{c}\text { Mycelium } \\
\text { moan } \\
\text { dry wt. } \\
\text { (g./100 ml.) }\end{array}$ & Fat (g.) & $\begin{array}{c}\text { Fat } \\
\text { g-/ / } 00 \mathrm{~g} . \\
\text { dry } \\
\text { mycelium }\end{array}$ & $\begin{array}{c}\text { Nitrogen } \\
\text { utilized } \\
\text { (g./100 ml.) }\end{array}$ & $\begin{array}{c}\text { Glucose } \\
\text { utilized } \\
(\mathrm{B} \cdot / 100 \mathrm{ml} \text {.) }\end{array}$ \\
\hline Ammonium phosphate & $\begin{array}{c}0.2285 \\
( \pm 0.0115)\end{array}$ & $\begin{array}{c}0.1016 \\
( \pm 0-0055)\end{array}$ & $\begin{array}{c}84 \cdot 00 \\
( \pm 2-05)\end{array}$ & 0.0050 & 0.94 \\
\hline Aspartic acid & $\begin{array}{c}0-8171 \\
( \pm 0.0045)\end{array}$ & $\begin{array}{c}0-0016 \\
( \pm 0-0042)\end{array}$ & $\begin{array}{c}29 \cdot 72 \\
( \pm 1.06)\end{array}$ & $0 \cdot 0089$ & 0.96 \\
\hline Arginine & $\begin{array}{c}0.8528 \\
( \pm 0.0082)\end{array}$ & $\begin{array}{r}0.0514 \\
( \pm 0-0088)\end{array}$ & $\begin{array}{c}14+46 \\
( \pm 2-1 \theta)\end{array}$ & $0-0078$ & $0-70$ \\
\hline Lyaine & $\begin{array}{r}0.8254 \\
( \pm 0.0104)\end{array}$ & $\begin{array}{r}0.0518 \\
( \pm 0.0175)\end{array}$ & $\begin{array}{r}15.06 \\
( \pm 1.00)\end{array}$ & 0.0080 & $0-97$ \\
\hline Aspertgine & $\begin{array}{r}0.8295 \\
( \pm 0-061)\end{array}$ & $\begin{array}{c}0.0088 \\
( \pm 0.0124)\end{array}$ & $\begin{array}{c}19-01 \\
( \pm 8-10)\end{array}$ & $0 \cdot 0076$ & 0.89 \\
\hline Urea & $\begin{array}{c}0.8518 \\
( \pm 0-0111)\end{array}$ & $\begin{array}{c}0.0440 \\
( \pm 0-0013)\end{array}$ & $\begin{array}{r}12.58 \\
( \pm 0.78)\end{array}$ & 0.0075 & 0.81 \\
\hline Control & $\begin{array}{r}0.0086) \\
( \pm 0.0000)\end{array}$ & - & - & - & $0 \cdot 27$ \\
\hline
\end{tabular}

phosphate, and nitrate did not support growth. In contrast fat synthesis was in most cases poor on the media which contained the amino acids and urea; an exception was aspartic acid which gave results similar to the ammonium salt. There was a correlation between the amount of fat synthesized and the amount of nitrogen utilized. Uptake of nitrogen was greatest from the amino acid and urea media 
which supported only limited fat production, but was low from the media containing aspartic acid and ammonium phosphate. Glucose utilization was about the same in all media.

\section{Comparative rates of growth and fat synthesis}

The fungus was grown on basal salts medium $+1 \%(\mathrm{w} / \mathrm{v})$ glucose $+0.05 \%(\mathrm{w} / \mathrm{v})$ $\left(\mathrm{NH}_{4}\right)_{2} \mathrm{HPO}_{4}$. Three flasks were removed after various periods of incubation. As seen in Table 3, rapid formation of mycelium occurred and the maximum yield was

\section{Table 3. Rate of fat synthesis in Mortierella vinacea}

Cultures were grown on basal salts medium $+1 \%(w / v)$ glucose $+0.05 \%(w / v)$ $\left(\mathrm{NH}_{4}\right)_{2} \mathrm{HPO}_{4}$. Mean values from three replicate cultures with standard deviations are given. Glucose estimations were made on combined filtrates.

\begin{tabular}{|c|c|c|c|c|}
\hline Days & $\begin{array}{c}\text { Mycelium } \\
\text { mean } \\
\text { dry wt. } \\
\text { (g.) }\end{array}$ & Fat (g.) & $\begin{array}{c}\text { Fat } \\
\text { g. } / 100 \mathrm{~g} . \\
\text { dry } \\
\text { mycelium }\end{array}$ & $\begin{array}{c}\text { Glucose } \\
\text { utilized } \\
\text { g./100 ml. }\end{array}$ \\
\hline 2 & $\begin{array}{c}0.0694 \\
( \pm 0.0055)\end{array}$ & $\begin{array}{r}0.0022 \\
( \pm 0.0002)\end{array}$ & $\begin{array}{c}3.17 \\
( \pm 0.25)\end{array}$ & 0.28 \\
\hline 4 & $\begin{array}{r}0.2536 \\
( \pm 0.0264)\end{array}$ & $\begin{array}{c}0.0701 \\
( \pm 0.0062)\end{array}$ & $\begin{array}{c}27.68 \\
( \pm 1.51)\end{array}$ & $0 \cdot 60$ \\
\hline 6 & $\begin{array}{c}0.2970 \\
( \pm 0.0288)\end{array}$ & $\begin{array}{c}0.1370 \\
( \pm 0.0110)\end{array}$ & $\begin{array}{c}39 \cdot 13 \\
( \pm 2 \cdot 67)\end{array}$ & 0.92 \\
\hline 8 & $\begin{array}{c}0.2897 \\
( \pm 0.0240)\end{array}$ & $\begin{array}{c}0.1116 \\
( \pm 0.0097)\end{array}$ & $\begin{array}{r}38.53 \\
( \pm 3.11)\end{array}$ & $0 \cdot 94$ \\
\hline 11 & $\begin{array}{c}0.2806 \\
( \pm 0.0142)\end{array}$ & $\begin{array}{c}0.1327 \\
( \pm 0.1063)\end{array}$ & $\begin{array}{c}47 \cdot 30 \\
( \pm 5 \cdot 09)\end{array}$ & 0.95 \\
\hline 13 & $\begin{array}{r}0.2882 \\
( \pm 0.0210)\end{array}$ & $\begin{array}{c}0.1477 \\
( \pm 0.0091)\end{array}$ & $\begin{array}{c}51 \cdot 40 \\
( \pm 3 \cdot 14)\end{array}$ & 0.96 \\
\hline 15 & $\begin{array}{r}0.2789 \\
( \pm 0.0246)\end{array}$ & $\begin{array}{c}0.1348 \\
( \pm 0.0125)\end{array}$ & $\begin{array}{c}48.27 \\
( \pm 4.55)\end{array}$ & 1.00 \\
\hline 18 & $\begin{array}{c}0.2887 \\
( \pm 0.0258)\end{array}$ & $\begin{array}{r}0.1342 \\
( \pm 0.0154)\end{array}$ & $\begin{array}{c}47 \cdot 32 \\
( \pm 5 \cdot 24)\end{array}$ & $1 \cdot 00$ \\
\hline 20 & $\begin{array}{r}0.2742 \\
( \pm 0.0221)\end{array}$ & $\begin{array}{c}0.1838 \\
( \pm 0.0061)\end{array}$ & $\begin{array}{c}46 \cdot 16 \\
( \pm 1 \cdot 89)\end{array}$ & $1 \cdot 00$ \\
\hline
\end{tabular}

obtained at 6 days, the amount of mycelium remaining fairly constant for the following 14 days. Utilization of glucose followed a linear pattern, $30 \%(\mathrm{w} / \mathrm{w})$ utilization after 2 days, $60 \%$ after 4 days and $90 \%$ after 6 days; average uptake $0 \cdot 15 \mathrm{~g}$. glucose $/ 100 \mathrm{ml}$. medium/day.

The accumulation of fat reached a maximum after 13 days. During the initial stages of growth, fat synthesis proceeded rapidly and this condition was maintained for 6 days, after which the rate of synthesis decreased. At this stage the amount of fat in the mycelium was increasing, but there was no simultaneous increase in weight of mycelium. It is likely that much of the fat formed after the 6th to the 13th day, must have been derived from some other non-fat reserve in the mycelium.

\section{The effect of the $C: N$ ratio of the culture medium} on growth and fat synthesis

Media containing glucose and $\left(\mathrm{NH}_{4}\right)_{2} \mathrm{HPO}_{4}$ were prepared in which carbon and nitrogen were present in ratios of $10: 1,25: 1,50: 1$ and $80: 1$. The results are shown in Table 4.

On medium $1(\mathrm{C}: \mathrm{N}=10: 1)$ and medium $2(\mathrm{C}: \mathrm{N}=25: 1)$ maximum production 
Table 4. The influence of the $C: N$ ratio in the growth medium on the formation of fat in Mortierella vinacea

Medium 1. $C: N=10: 1$, glucose $0 \cdot 212$ g. $/ 100 \mathrm{ml}$. Medium 2. $C: N=25: 1$, glucose $0.53 \mathrm{~g} . / 100 \mathrm{ml}$. Medium 3. $\mathrm{C}: \mathrm{N}=50: 1$, glucose $1.06 \mathrm{~g} . / 100 \mathrm{ml}$. Medium 4. $\mathrm{C}: \mathrm{N}=$ $80: 1$, glucose 1.696 g. $/ 100 \mathrm{ml}$.

Concentration of $\left(\mathrm{NH}_{4}\right)_{2} \mathrm{HPO}_{1}$ in all media was $0.05 \mathrm{~g} . / 100 \mathrm{ml}$. Three replicate flasks were harvested at each sampling time. Mean values with standard deviations are given. Glucose analyses were made on combined filtrates.

\begin{tabular}{|c|c|c|c|c|}
\hline Days & $\begin{array}{c}\text { Mycelium } \\
\text { mean } \\
\text { dry wt. } \\
\text { (g./100 ml.) }\end{array}$ & Fat (g.) & $\begin{array}{c}\text { Fat } \\
\text { g. } / 100 \mathrm{~g} . \\
\text { dry } \\
\text { mycelium }\end{array}$ & $\begin{array}{c}\text { Glucose } \\
\text { utilized } \\
\text { (g./100 ml.) }\end{array}$ \\
\hline \multicolumn{5}{|c|}{ Medium 1} \\
\hline 3 & $\begin{array}{c}0.1208 \\
( \pm 0.0078)\end{array}$ & $\begin{array}{c}0.0038 \\
( \pm 0.0002)\end{array}$ & $\begin{array}{c}3 \cdot 38 \\
( \pm 0 \cdot 25)\end{array}$ & $0 \cdot 172$ \\
\hline 6 & $\begin{array}{c}0 \cdot 1125 \\
( \pm 0.0071)\end{array}$ & $\begin{array}{c}0.0054 \\
( \pm 0.0002)\end{array}$ & $\begin{array}{c}4.74 \\
( \pm 0.19)\end{array}$ & 0.212 \\
\hline 9 & $\begin{array}{c}0 \cdot 1038 \\
( \pm 0 \cdot 0025)\end{array}$ & $\begin{array}{c}0.0101 \\
( \pm 0.0034)\end{array}$ & $\begin{array}{r}9 \cdot 76 \\
( \pm 3 \cdot 30)\end{array}$ & $0 \cdot 212$ \\
\hline 12 & $\begin{array}{c}0 \cdot 1003 \\
( \pm 0 \cdot 0032)\end{array}$ & $\begin{array}{c}0.0074 \\
( \pm 0.0017)\end{array}$ & $\begin{array}{c}7 \cdot 42 \\
( \pm 1 \cdot 80)\end{array}$ & $0 \cdot 212$ \\
\hline 15 & $\begin{array}{c}0.0914 \\
( \pm 0.0056)\end{array}$ & $\begin{array}{c}0.0055 \\
( \pm 0.0006)\end{array}$ & $\begin{array}{c}5.61 \\
\pm 0.92)\end{array}$ & 0.212 \\
\hline \multicolumn{5}{|c|}{ Medium 2} \\
\hline 3 & $\begin{array}{c}0.0988 \\
( \pm 0.0024)\end{array}$ & $\begin{array}{r}0.0064 \\
( \pm 0.0009)\end{array}$ & $\begin{array}{r}6.53 \\
( \pm 0.89)\end{array}$ & 0.46 \\
\hline 6 & $\begin{array}{r}0.0929 \\
( \pm 0.0075)\end{array}$ & $\begin{array}{r}0.0112 \\
( \pm 0.0013)\end{array}$ & $\begin{array}{c}12 \cdot 22 \\
( \pm 2 \cdot 20)\end{array}$ & $0 \cdot 49$ \\
\hline 9 & $\begin{array}{r}0.0905 \\
( \pm 0.0100)\end{array}$ & $\begin{array}{c}0.0130 \\
( \pm 0.0008)\end{array}$ & $\begin{array}{c}14 \cdot 43 \\
( \pm 1 \cdot 27)\end{array}$ & $0 \cdot 49$ \\
\hline 12 & $\begin{array}{c}0.0821 \\
( \pm 0.0037)\end{array}$ & $\begin{array}{c}0.0049 \\
( \pm 0.0002)\end{array}$ & $\begin{array}{c}5 \cdot 22 \\
( \pm 0 \cdot 98)\end{array}$ & 0.49 \\
\hline 15 & $\begin{array}{c}0.0826 \\
( \pm 0.0120)\end{array}$ & $\begin{array}{c}0.0044 \\
( \pm 0.0002)\end{array}$ & $\begin{array}{c}5 \cdot 07 \\
( \pm 0 \cdot 41)\end{array}$ & 0.50 \\
\hline \multicolumn{5}{|c|}{ Medium 3} \\
\hline $\mathbf{3}$ & $\begin{array}{c}0.2196 \\
( \pm 0.0052)\end{array}$ & $\begin{array}{c}0.0468 \\
( \pm 0.0047)\end{array}$ & $\begin{array}{r}21 \cdot 56 \\
( \pm 2 \cdot 70)\end{array}$ & 0.50 \\
\hline 6 & $\begin{array}{c}0.8122 \\
( \pm 0.0172)\end{array}$ & $\begin{array}{c}0.0786 \\
( \pm 0.0095)\end{array}$ & $\begin{array}{r}21 \cdot 59 \\
( \pm 2 \cdot 66)\end{array}$ & $1 \cdot 02$ \\
\hline 9 & $\begin{array}{c}0.3315 \\
( \pm 0.0065)\end{array}$ & $\begin{array}{c}0.1298 \\
( \pm 0.0146)\end{array}$ & $\begin{array}{c}39 \cdot 10 \\
( \pm \mathbf{3 . 5 8})\end{array}$ & $1 \cdot 06$ \\
\hline 12 & $\begin{array}{r}0.3292 \\
( \pm 0.0017)\end{array}$ & $\begin{array}{r}0 \cdot 1359 \\
( \pm 0.0019)\end{array}$ & $\begin{array}{c}40 \cdot 99 \\
( \pm 0 \cdot 83)\end{array}$ & 1.06 \\
\hline 15 & $\begin{array}{c}0.3289 \\
( \pm 0.0038)\end{array}$ & $\begin{array}{c}0 \cdot 1514 \\
( \pm 0 \cdot 0024)\end{array}$ & $\begin{array}{r}46 \cdot 22 \\
( \pm 1 \cdot 19)\end{array}$ & $1 \cdot 06$ \\
\hline \multicolumn{5}{|c|}{ Medium 4} \\
\hline 3 & $\begin{array}{c}0.2338 \\
( \pm 0.0016)\end{array}$ & $\begin{array}{c}0.0600 \\
( \pm 0.0035)\end{array}$ & $\begin{array}{c}25 \cdot 34 \\
( \pm 1 \cdot 71)\end{array}$ & 0.292 \\
\hline 6 & $\begin{array}{c}0.3826 \\
( \pm 0.0062)\end{array}$ & $\begin{array}{c}0.2350 \\
( \pm 0.0172)\end{array}$ & $\begin{array}{c}60.56 \\
( \pm 3 \cdot 36)\end{array}$ & $1 \cdot 270$ \\
\hline 9 & $\begin{array}{c}0.4567 \\
( \pm 0.0082)\end{array}$ & $\begin{array}{c}0.3033 \\
( \pm 0.0054)\end{array}$ & $\begin{array}{c}66 \cdot 47 \\
( \pm 1 \cdot 62)\end{array}$ & $1 \cdot 696$ \\
\hline 12 & $\begin{array}{r}0.4749 \\
( \pm 0.0167)\end{array}$ & $\begin{array}{r}0.2852 \\
( \pm 0.0380)\end{array}$ & $\begin{array}{r}61 \cdot 45 \\
( \pm 7 \cdot 70)\end{array}$ & $1 \cdot 696$ \\
\hline 15 & $\begin{array}{r}0.4502 \\
( \pm 0.0072)\end{array}$ & $\begin{array}{c}0.2809 \\
( \pm 0.0028)\end{array}$ & $\begin{array}{r}62.05 \\
( \pm 1.95)\end{array}$ & $1 \cdot 696$ \\
\hline
\end{tabular}


of mycelium occurred after 3 days, followed by autolysis. The maximum yield of mycelium on these media was $20-30 \%(w / w)$ of that obtained on medium 3 $(C: N=50: 1)$ and medium $4(C: N=80: 1)$.

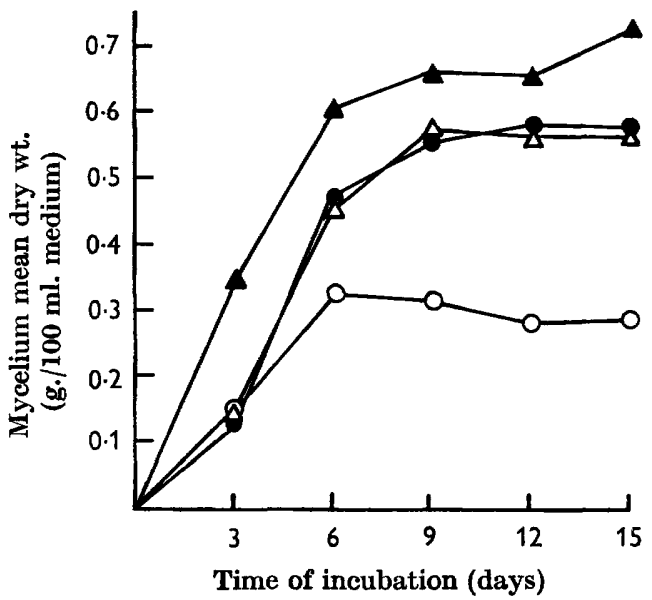

Fig. 1

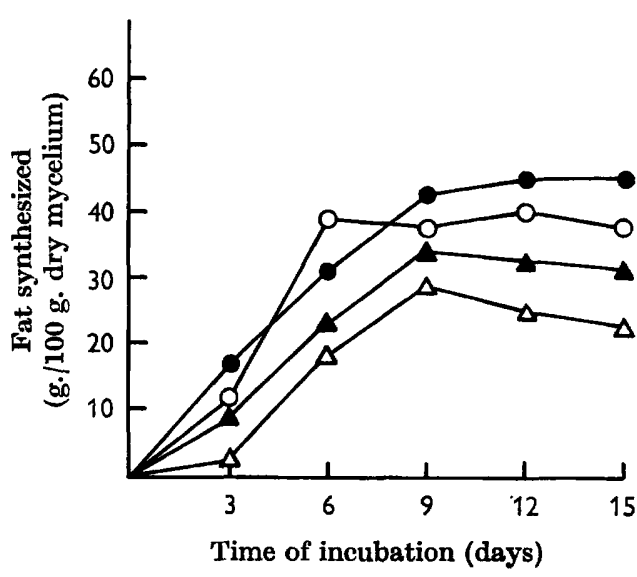

Fig. 2

Fig. 1. Growth of Mortierella vinacea on media containing various concentrations of glucose and ammonium phosphate, but maintaining a constant $C: N$ ratio of $40: 1$ in the medium - $-\mathrm{O}-$, medium 5, glucose $1 \mathrm{~g} . / 100 \mathrm{ml}$., $\left(\mathrm{NH}_{4}\right)_{2} \mathrm{HPO}_{4} \mathrm{0} .05 \mathrm{~g} .1100 \mathrm{ml}$; $-1-$, medium 6, glucose $2 \mathrm{~g} . / 100 \mathrm{ml}$., $\left(\mathrm{NH}_{4}\right)_{2} \mathrm{HPO}_{4} 0.10 \mathrm{~g} . / 100 \mathrm{ml}$; $-\triangle-\triangle-$, medium 7 , glucose $5 \mathrm{~g} . / 100 \mathrm{ml}$., $\left(\mathrm{NH}_{4}\right)_{2} \mathrm{HPO}_{4} 0.25 \mathrm{~g} / 100 \mathrm{ml}$; $-\Delta-\Lambda-$, medium 8 , glucose $10 \mathrm{~g} . / 100 \mathrm{ml}$., $\left(\mathrm{NH}_{4}\right)_{2} \mathrm{HPO}_{4} 0.50 \mathrm{~g} . / 100 \mathrm{ml}$.

Fig. 2. Fat accumulation in the mycelium of Mortierella vinacea grown on media containing various concentrations of glucose and ammonium phosphate, but maintaining a constant $C: N$ ratio of $40: 1$ in the medium. - $-0-$, medium 5 , glucose $1 \mathrm{~g} . / 100 \mathrm{ml}$., $\left(\mathrm{NH}_{4}\right)_{2} \mathrm{HPO}_{4}$ 0.05 g./100 ml.; - - - medium 6, glucose $2 \mathrm{~g} . / 100 \mathrm{ml}$., $\left(\mathrm{NH}_{4}\right)_{2} \mathrm{HPO}_{4}$ 0.10 g. $/ 100 \mathrm{ml}$; $\rightarrow \triangle-\triangle-$, medium 7 , glucose 5 g. $/ 100 \mathrm{ml}$., $\left(\mathrm{NH}_{4}\right)_{2} \mathrm{HPO}_{4} 0.25 \mathrm{~g} . / 100 \mathrm{ml}$; $-\Delta-\triangle-$, medium 8, glucose $10 \mathrm{~g} .100 \mathrm{ml}$., $\left(\mathrm{NH}_{4}\right)_{2} \mathrm{HPO}_{4} 0.50 \mathrm{~g} . / 100 \mathrm{ml}$.

Table 5. The influence of the $C: N$ ratio in the growth medium on the efficiency of conversion of glucose to fat by Mortierella vinacea

Details of media are given in Table 4.

Fat

coefficient*

$\begin{array}{lr}\text { Medium 1 } & \mathbf{4} \cdot 74 \\ \text { Medium 2 } & 2 \cdot 64 \\ \text { Medium 3 } & 14 \cdot 34 \\ \text { Medium 4 } & 17 \cdot 74\end{array}$

* The fat coefficient is defined as the amount of fat produced by the organism per $100 \mathrm{~g}$. carbon source utilized. The coefficients given here are calculated from data obtained at the time of maximum fat accumulation in the mycelium.

An increase in fat accumulation resulted from supplying the fungus with increased carbohydrate. As shown in Table 4, the culture growing on medium 4 produced mycelium which contained over $60 \%(w / w)$ fat. This yield is high in comparison with reports for other fungi. The results obtained suggest that the balance 
between fat synthesis and protein synthesis was affected by the amounts of carbon and nitrogen available. Consideration of the fat coefficients for each culture at the time of maximum fat synthesis (Table 5) suggests that protein formation may have been occurring to a greater extent in cultures growing on low carbon media.

\section{The influence of concentration of carbon and nitrogen at a constant $C: N$ ratio}

Media containing a range of concentrations of glucose and $\left(\mathrm{NH}_{4}\right)_{2} \mathrm{HPO}_{4}$ but maintaining a constant $C: N$ ratio of $40: 1$ were prepared. Cultures were harvested after various periods of incubation and the results are given in Figs. 1 and 2. A tenfold increase in glucose concentration in medium $8(10 \%, \mathrm{w} / \mathrm{v}$, glucose) over medium 5 ( $1 \%$ glucose) gave an increased yield of mycelium. This increase was over $100 \%$. The growth produced on medium 6 ( $2 \%$ glucose) and medium 7 ( $5 \%$ glucose) was the same. The highest yields on these media were almost twice that on medium 5. There were noticeable differences in the times at which maximum growth occurred on the different media. On medium 5 maximum growth was produced after 6 days, on media 6 and 7 at 9 days, and on medium 8 mycelium formation was still taking place after 15 days.. These results are shown in Fig. 1.

The corresponding rates of fat synthesis and yields of fat are shown in Fig. 2. Fat synthesis proceeded more rapidly and more fat was formed (per g. mycelium) by the cultures growing on medium 5 ( $1 \%$ glucose). There were different rates of fat synthesis in the four cultures during the first 3 days, the cultures growing on medium 5 producing most fat. After this initial period the rates of synthesis in the four cultures were about equal.

\section{DISCUSSION}

The nature of the carbon and nitrogen sources, together with the relative proportions of each, have a marked effect on growth and fat synthesis in Mortierella vinacea. The results given here show also that the formation of fat is an important aspect of the general metabolism of this fungus.

Nutrients which support good growth do not necessarily support the synthesis of large amounts of reserve food products. Some nutrients are used solely for the production of new protoplasm which contains little reserves, others support the formation of abundant reserves of a particular type as well as new protoplasm.

A wide range of carbon sources are utilized by fungi; glucose and maltose give rise to the highest yields of mycelium for most, e.g. Penicillium lilacinum (Philip \& Walker, 1958), Aspergillus nidulans (Naguib, 1959). These fungi produced more fat from glucose than maltose and it was suggested that maltose favoured the accumulation of polysaccharides. In contrast, maltose was better than glucose for growth of Mortierella vinacea but the amount of fat synthesized was similar for both sugars.

Synthesis of fat on media containing inorganic forms of nitrogen occurs to varying extent. There are several reports that this form of nitrogen stimulates the formation of more fat than organic nitrogen sources, although mycelium production is better on the latter type of medium. This has been shown by Turpenein (1936) with Geotrichoides and by Gad \& El-Nockrashy (1960) with Aspergillus fumigatus. Naguib \& Saddik (1960) found that $A$. nidulans behaved differently, producing 
larger yields of fat on medium containing asparagine than on media containing nitrate or ammonium salts.

The time at which fat formation occurs also varies. Naguib (1959) found that Aspergillus nidulans synthesized its fat during the later stages of growth. He found that at this stage increases in the weight of mycelial felts were due mainly to accretion of fat. With the organism used in this study, however, the processes of formation of new protoplasm and fat occurred simultaneously and some of the fat produced was utilized later in some cultures. This observation supports the view of Gyllenberg \& Raitio (1952) who found that fat synthesized in the mycelium of a Penicillium species was later used when the fungus was starved of nutrients.

The effects of concentration of carbon and nitrogen in the medium have been investigated with a number of organisms. All behave in a similar manner, producing more fat when the amount of carbon in the medium is increased. The effects of increasing the concentrations of these two nutrients but maintaining a constant $C: N$ ratio have not been studied previously. It is significant to note that whilst an increase in the amount of carbon and nitrogen in the medium was correlated with increased yield of mycelium, this was not so for fat synthesis. The concentration of nutrients in a medium is obviously of as much importance as their relative proportions in the control of metabolic processes in fungi.

We wish to thank Mrs M. Turner for helpful discussion and comments. This work was carried out during the tenure of a D.S.I.R. Research Studentship awarded to one of us (J.F.P.).

\section{REFERENCES}

GAD, A. M. \& EL-Nockrashy, A. S. (1960). Microbiological synthesis of fat. II. Effect of different cultural conditions on the synthesis of fat by Aspergillus fumigatus. J. Chem. U.A.R. 3, 57.

Galloway, L. D. (1949). Patent Prov. Spec. 32887.

Gyllenbeng, H. \& Ratio, A. (1952). Studies on the decomposition of cellular lipids of moulds. Phys. Plant. 5, 367.

NaGuib, K. (1959). Growth and metabolism of Aspergillus nidulans Eidam in surface culture. Can. J. Bot. 37, 353.

NAGUIB, K. \& SADDIK, K. (1960). Growth and metabolism of Aspergillus nidulans Eidam on different nitrogen sources in synthetic media conducive to fat formation. Can. $J$. Bot. 38, 618.

Phinip, S. E. \& Walker, T. K. (1958). Mycological formation of fat. V. Factors which influence the formation of fat in surface cultures of Penicillium lilacinum Thom. J. Sci. Fd. Agric. 9, 228.

TURNer, M. (1956). Mortierella globulifera. Rostrup. Trans. Br. mycol. Soc. 39, 291.

Turpenein, O. (1936). Studies on microbiological lipides. The formation and chemical composition of lipides of Geotrichoides sp. Langeron \& Tallice. Ann. Acad. Sci. fenn. A, 46, 110.

WeTtER L. R. (1952). The proteolytic enzymes of micro-organisms. IV. Partial purification of extracellular protease from Mortierella renispora Dixion-Stewart. Can. J. Bot. 30, 685 .

Woodbine, M. (1959). Microbiological fat: Micro-organisms as potential fat producers. Prog. ind. Microbiol. I.

Woonbine, M., Gregory, M. E. \& Watker, T. K. (1951). Microbiological synthesis of fat. Preliminary survey of the fat producing moulds. J. Expl. Bot. 2, 204.

YEMM, E. W. \& WrLus, A. J. (1954). The estimation of carbohydrates in plant extracts by anthrone. Biochem. J. 57, 508. 